\title{
"Good Governing Poverty Alleviation” Through The PKH Policy - Independent Women's Group in Poverty Reduction in Batu City (Study at Batu City Social Service)
}

\author{
Indah Dwi Maulana, Jainuri, Hevi Kurnia Hardini \\ Email : indahdwimaulana@gmail.com, hevi.hardini@gmail.com, Jaenuri@gmail.com
}

University of Muhammadiyah Malang

Article Info :

\author{
Article history : \\ Received : August 15, 2019 \\ Revised : August 21, 2019 \\ Accepted : October 11, 2019 \\ ISSN 2620-8091, Online 2620-3812
}

\section{ABSTRAK}

Good Governance Poverty Alleviation adalah program pengetasan kemiskinan dengan menerapkan model Tata Kelola yang baik dalam konteks ini dalam Program Keluarga Harapan yang melibatkan KPM para pelaku di sektor negara, masyarakat dan sektor swasta. Mengatasi masalah kemiskinan Pemerintah Kota Batu sesuai dengan model Tata Pemerintahan yang Baik melalui pola kemitraan yang dibangun dengan sektor swasta, KPM dan Dinas Sosial Kota Batu diharapkan untuk menciptakan KPM yang mampu mencoba mengembangkan kreativitas mereka untuk bangkit dari kemiskinan untuk diri mereka sendiri dan keluarga mereka.

Please Cite This Articel As : Indah Dwi Maulana et al., "Good Governing Poverty Alleviation” Through The PKH Policy - Independent Women's Group in Poverty Reduction in Batu City (Study at Batu City Social Service): Journal of Local Government Issues (LOGOS), https://doi.org/10.22219/LOGOS.Vol2.No2.193-209 
Penelitian ini menggunakan metode deskriptif kualitatif dengan teknik pengumpulan data seperti observasi, wawancara dan dokumentasi serta data lain yang mendukung penelitian ini baik primer maupun sekunder. Hasil dari penelitian ini, yaitu kebijakan ini sebenarnya sudah terintegrasi dengan baik tetapi dalam implementasi di tingkat daerah, dalam hal ini Kota Batu belum menunjukkan model integrasi karena sesuatu belum terwujud secara normatif. Yang dimaksud adalah Standar Operasional Prosedur belum diatur dalam kebijakan ini. Ada dinamika seperti kapasitas sumber daya manusia KPM yang masih di bawah standar sehingga implementasi kebijakan dan antusiasme pribadi dalam menerapkan kebijakan ini, memberdayakan perempuan melalui KPM adalah satu upaya meningkatkan ekonomi KPM melalui skema kemitraan dengan pengusaha di Kota Batu.

Kata kunci: Pengentasan Kemiskinan, Tata Kelola yang Baik, Penanggulangan Kemiskinan, KPM, PKH.

\section{INTRODUCTION}

Excellent Governance Poverty Alleviation is a poverty alleviation program by applying the Good Governance governance model in this context in the Family Hope Program - KPM involving state, community and private sector actors. Good governance is an alternative in solving problems, which was initially popularized by Word Bank, and UNDP has been applied to various institutions at the government level. Good governance has three domains, namely the state, private sector and society that have developed with various variations. These three domains are the pillars of good governance. These stakeholders are interconnected, both in terms of cooperation and conflict (Soeun 2005).

Poverty is a social problem that is presented to the community, especially in developing countries (Suharto, 2005). Poor people, men and women, are not fulfilled the fundamental rights to maintain and develop a decent life. The 1945 Constitution of the 4th century which reads the purpose of the Republic of Indonesia is to protect the entire Indonesian nation as well as the Constitution of the Republic of Indonesia. Article 34, paragraph 1 of the 1945 Constitution abandoned the state nurtures children ". Poverty becomes a problematic circle to find a way out; in other words, poverty does not only use one method, because it must involve various sectors and actors in its response.

The problem of poverty in Indonesia is an ongoing study Minimum standard needs, to meet food and non-food needs commonly called the poverty line or poverty line Food Poverty Line (GKM) is the value of minimum food needs which is equal to 2100 kilocalories per capita per day, the basic food needs package is represented by 52 types of commodities (grains, tubers, fish, meat, meat, protein and milk, vegetables, beans), fruits, oils and fats) while the Non-Food Poverty Line (NFPL) is the minimum need for housing, clothing, education and health, the non-food necessity commodity package is represented by 51 types of commodities in housing and 47 types of commodities in rural areas, BPS 2019.

\section{Tabel 1.1 Jumlah Penduduk Miskin di Indonesia}

\begin{tabular}{|l|l|l|l|}
\hline Ruang Lingkup & Tahun & Jumlah & Persentasi \\
\hline Indonesia & 2017 & 26,58 juta orang & $10,12 \%$ \\
\cline { 2 - 4 } & 2018 & 25,95 juta orang & $9,82 \%$ \\
\hline
\end{tabular}

Please Cite This Articel As : Indah Dwi Maulana et al., "Good Governing Poverty Alleviation” Through The PKH Policy - Independent Women's Group in Poverty Reduction in Batu City (Study at Batu City Social Service): Journal of Local Government Issues (LOGOS), https://doi.org/10.22219/LOGOS.Vol2.No2.193-209 


\begin{tabular}{|l|l|l|l|}
\hline \multirow{2}{*}{ Perkotaan } & 2017 & 10,27 juta orang & $7,26 \%$ \\
\cline { 2 - 4 } & 2018 & 10,14 juta orang & $7,02 \%$ \\
\hline \multirow{2}{*}{ Pedesaan } & 2017 & 16,31 juta orang & $13,47 \%$ \\
\cline { 2 - 4 } & 2018 & 15,81 juta orang & $13,20 \%$ \\
\hline
\end{tabular}

\section{Source: the central statistics}

Based on the above data, it can be seen that there has been a decline in poverty rates in both urban and rural areas. In this case, it cannot be denied even though there has been a decline in the number and number of people who are shackled in poverty; it does not mean that the government is underestimating this poverty issue. The Central Government and Regional Governments work together in poverty, alleviation both nationally and locally.

In this case, the role of government is significant in overcoming the problem of poverty. Various programs have been implemented by the government to reduce poverty in Indonesia so that it decreases. One of the poverty alleviation programs is through the PKH. Based on Regulation of the Minister of Social Affairs of the Republic of Indonesia Number 1 of 2018 concerning PKH, it is stipulated to support the implementation of a planned, directed and sustainable distribution of social protection programs in the form of PKH as conditional social assistance aimed at reducing the burden of spending and increasing the income of poor and vulnerable families. In this case the distribution of PKH social assistance (Bansos) as an effort to minimize poverty and inequality by supporting access to health, education and social welfare to improve the quality of life of poor and vulnerable families. PKH social assistance in the form of money to someone, family, group or community that is poor, unable and vulnerable to social risks. This is also stated in Law No. 11 of 2009 concerning Social Welfare, that in order to create a decent and dignified life, and to fulfil the rights to the basic needs of citizens for the achievement of social welfare, the state organizes social welfare services in a planned, directed and sustainable manner.

Before, the distribution of PKH social assistance to beneficiary families in cash, but over time there was a change in the distribution of social assistance. Following the latest technical instructions and regulated in Presidential Regulation No. 63 of 2017 concerning Distribution of Non-Cash Social Assistance, it is explained that the distribution of social assistance is the implementation of poverty alleviation programs that include social protection, social security, social empowerment, social rehabilitation, and essential services. During this time, the government continues to strive to create and implement poverty reduction programs.

PKH is deconcentration program from the central government to local governments, in this case, Kota Batu. Deconcentration is the delegation of part of governmental affairs which becomes the authority of the Government to the governor as the representative of the Government, to vertical agencies in certain areas, and the governor and regent mayor as the person in charge of general government affairs. This is based on the Minister of Social Affairs Regulation Number 18 the Year 2017 concerning Delegation of Deconcentration

Please Cite This Articel As : Indah Dwi Maulana et al., "Good Governing Poverty Alleviation” Through The PKH Policy - Independent Women's Group in Poverty Reduction in Batu City (Study at Batu City Social Service): Journal of Local Government Issues (LOGOS), https://doi.org/10.22219/LOGOS.Vol2.No2.193-209 
Authority and Assignment of Assistance Tasks to Provincial Social Offices and District City Regional Social Services for Fiscal Year 2018, in Chapter III Articles 6 and 11.

One of the regional level implementers, namely the Batu City Government, is one of the cities implementing PKH. Based on data from the Central Statistics Agency of Batu City, the Poverty Line and Poor Population in Batu City in 2012 to 2017. In 2012 the number of poor people in Batu City was 8,700 people, in 2013 there were 9,400 people, in 2014 there were 9,100 people, in 2015 there were 9,430 people, souls, in 2016 as many as 9,050 people, in 2017 the number of poor people in Batu City was 8,770 people. In 2018 the number of poor people in Batu City was 7,980 people.

The number of poor people in Kota Batu fluctuates every year. Therefore, a response program is needed to reduce poverty. In this case, the poverty alleviation program does not only provide social assistance in the form of money. However, to be able to be separated from poverty, the City Government of Batu has a government engagement initiative as part of the Good Governance actor in the poverty alleviation policy, namely Mayor Regulation Number 26 of 2015 concerning the Acceleration of Poverty Management through the Pattern of KPM Partnership. PKH-KPM is an effort to reduce poverty in the context of the actor Good Governance, which, as a component involves the role of government a supporter in this policy.

Women become one of the actors in the context of Good Governance as a Society that will be empowered by the government and in collaboration with the private sector in empowering the community, especially women who are PKH participants. The emergence of this policy in order to improve the welfare of the people of Batu, especially PKH participants who live in poverty through various programs that are able to support the independence of poor women so that they are able to escape from the poverty line that is the responsibility of the Regional Government, it is necessary to accelerate the handling of the problem of poverty in the City of Batu. In this policy, women are targeted in poverty alleviation. Women who as PKH participants are formed as KPM, which aims to create a KPM that can try and develop their creativity to rise from poverty both for themselves and their families. This policy also invites the private sector to help overcome the poverty problems that exist in Kota Batu specifically through the empowerment of women (PKH participants) as the target of this policy.

Therefore, in this case the researcher looks at the problem of poverty in the city of Batu and the researcher wants to see how the Government of the City of Batu cope with the problem of poverty through the role of the community especially women in accordance with the Mayor Regulation Number 26 of 2015 concerning the Acceleration of Poverty Management through the Partnership Pattern PKH-KPM.

\section{LITERATUR REVIEW}

\section{a. Good Governance in Poverty Alleviation Programs}

Word Bank defines good governance as management of substantial development that is responsible and in line with the principles of democracy and efficient markets, avoiding misallocation

Please Cite This Articel As : Indah Dwi Maulana et al., "Good Governing Poverty Alleviation” Through The PKH Policy - Independent Women's Group in Poverty Reduction in Batu City (Study at Batu City Social Service): Journal of Local Government Issues (LOGOS), https://doi.org/10.22219/LOGOS.Vol2.No2.193-209 
of investment funds and preventing corruption both politically and administratively, carrying out budgetary discipline and creating legal and political frameworks for the growth of activities business. The concept of Good Governance has three elements of Government, Private Parties and Communities in poverty reduction through the policy of the Family Hope Program in Kota Batu. The focus of this research is the governance model of "Good Governing Poverty Alleviation" through the PKH Policy - KPM in Poverty Alleviation in Batu City.

\section{b. Integrated Policy in Poverty Reduction}

The integrated policy is an integrated policy that is an integral part of work-life and is actively controlled and supported by top management so that implementation is a natural part of what has been planned. The basic requirements for policies to qualify as' integrated 'are completeness, aggregation and consistency (Meijers and Stead 2004). Based on the above understanding, it can be concluded that integrated policy is a policy that is interrelated with one another.

An integrated policy one example is the Central Government's policy, in this case, the Ministry of Social Affairs to tackle the problem of poverty. The Ministry of Social Affairs created a program called the Family Hope Program. The Harapan Harapan Family Program is non-cash social assistance provided to beneficiary families as a target where poverty standards are below $15 \%$. PKH has 3 (three) components in poverty alleviation efforts, namely, Education, Health and Social Welfare. From the three components, it can be seen that poverty reduction can not only be solved by just one component. However, poverty alleviation must link one component to another.

\section{c. PKH and the KPM}

PKH is a conditional social assistance program for poor and vulnerable families or individuals registered in the integrated data for the reduced handling program, processed by the Social Welfare Data and Information Center and designated as PKH beneficiary families. PKH is a program derived from the Central Government's policy and implemented by the Regional Government in this study, Batu City. The Policy of the KPM (KPM) is present in Batu City as a form of follow-up to the Family Hope Program and innovation from the Batu City Government, especially the Batu City Social Service in Overcoming the existing poverty problem. KPM is a group that has been formed in the PKH, in the form of empowering women in the economic field to create a group of women who can try and develop their creativity to rise from poverty both for themselves and their families. Participants from the KPM are groups consisting of women participating in the Harapan Family Program according to their respective regions in Batu City.

In terms of implementation, a KPM forms a home-based business both food, drink, and savings and loan services and then partners with the private sector, in this case, the role of the private sector is given the most comprehensive opportunity to play an active role in poverty reduction and the private

Please Cite This Articel As : Indah Dwi Maulana et al., "Good Governing Poverty Alleviation” Through The PKH Policy 
party intended is an entrepreneur who is domiciled and conducting business activities in Batu City.

\section{d. Welfare State}

Welfare state becomes a necessity that continues to dynamically follow the situation and development of society (Susetio 2007). At present, the concept of the welfare state has created three regimes by Esping Anderson's poured in a book entitled "The Three Worlds of Welfare Capitalism", namely Liberal, Social Democratic, and Conservative (Susetio 2007). The idea regarding the Welfare State is not new. The idea related to Welfare State has existed since the age of the 18th century (Sukmana 2017). The Welfare State is a social welfare system that seeks to exaggerate the role of the state (government) to allocate public funds to ensure the fulfilment of the basic needs of its citizens (Suharto 2005).

The concept of the welfare state is. First, the state is not the only source of welfare; Most people get support through labour market for most of their lives, Individuals can secure their welfare through private insurance and private charities, family and friends also provide welfare. Secondly, it does not mean that if the state funds a service, then the service must be produced publicly, Welfare is a mosaic, with the diversity of both and the way they are delivered. The term welfare state can be considered as an abbreviation for the role of the state in education, health, housing, reduced assistance, social insurance and other social services (Barr 2012).

\section{METODHS}

In a research method that is needed, this study uses qualitative methods. Qualitative Method is a naturalistic research method because the results of the data are really by the conditions that are appropriate in the field (Sugiyono 2014). Descriptive research type, descriptive research is a type of research that has the aim to complete a complete systematic analysis of the problem (Poerwanti 1998). Research Focus aimed at research. The research conducted avoids collecting data in a very general field with the formulation of the problem or research objective. Determination of the people interviewed is done purposively, chosen with specific considerations and objectives, (Sugiyono 2008). While the data analysis techniques used are technical qualitative data analysis which includes data collection, data reduction, data review, and conclusion (Miles, Huberman et al. 1994).

In qualitative research, the data collection process consists of three essential things, such as observation, interviews, and documentation. Data analysis is an effort made by researchers to collect data; then the data are sorted into one, synthesizing, then the data is found and found its pattern, find what is essential or not, and decide what has been told or presented by others (Bogdan and Biklen 2007). States that data analysis is the process of searching and compiling systematically data obtained from interviews, field notes, and other materials (Sugiyono 2014).

Please Cite This Articel As : Indah Dwi Maulana et al., "Good Governing Poverty Alleviation” Through The PKH Policy 


\section{RESULTS AND DISCUSSION}

The problem of poverty becomes a problem for all regions or regions in Indonesia, including Batu City. Based on Law Number 11 the Year 2009 regarding Social Welfare, poverty alleviation is a policy, program and activity carried out on people, families, or communities who do not have a source of livelihood or cannot meet the needs of decent humanity.

One form of poverty reduction from the Central Government, in this case, is the Ministry of Social Affairs through the Family Hope Program (PKH) which is a conditional social assistance program for impoverished households and vulnerable people who are sick. This has been regulated in Regulation of the Minister of Social Affairs of the Republic of Indonesia Number 1 of 2018 concerning Family Hope Program (PKH). However, it did not stop there with the efforts of the Ministry of Social Affairs in overcoming the problem of poverty nationally, in this case Kota Batu, which is one of the autonomous regions, made policies to overcome poverty through the Mayor's Regulation No. 26 of 2015 concerning the Acceleration of Poverty Management through Partnership Patterns The Harapan Harapan Family Program Women's Group. In this policy, the empowerment of women is evident, where poverty alleviation policies make women the main actors in this policy.

a. KPM in Poverty Reduction in Batu City.

\section{Chronology of PKH Policy - KPM in Batu City.}

The existence of Socio-Economic Prone Women is one of the factors of poverty that always surrounds women, so there is a need to overcome the problem of poverty that involves women in it. Women who have a PRSE background are one of the processes to form a poverty reduction policy in Kota Batu, namely the Mayor's Regulation No. 26 of 2015 concerning the Acceleration of Poverty Management through the Partnership Pattern of the KPM Family Program Harapan. Women with Socio-Economic Principles are women who because of their poverty, backwardness and ignorance experience a functional disruption in their social and or economic life so that they have difficulty in carrying out their social roles. Women are a vulnerable group to become victims of crime and originated from the problem of poverty; women in poverty become perpetrators and victims due to development injustice. Women are the people who maintain harmony and continuity for future generations.

From this, women have the right to demand an education, health and proper empowerment to prepare a better generation in the future. When women are empowered, they will be able to rid themselves and their families from poverty. The existence of women who have had business embryos previously runs passively. In this prevention policy the Kota Batu Social Service does not only create groups from the basis of groups that have embryos only, but women who belong to

Please Cite This Articel As : Indah Dwi Maulana et al., "Good Governing Poverty Alleviation” Through The PKH Policy 
beneficiary families either as participants or family members of PKH participants who cannot at all moving in this matter in the economic field, that then led to the emergence of poverty reduction policies to empower them in the form of the Mayor's Regulation Batu No. 26 of 2015 concerning the Acceleration of Poverty Management through the Partnership Pattern of the KPM Family Program Harapan. So, some of these KPMs already have business embryos, and some KPMs previously did not have business embryos.

In this poverty reduction policy, we can see that women are considered as social creatures who can rid themselves and their families from poverty through the economic empowerment of productive businesses formed in the KPM container. The role of women today is not like before; now women are seen not only as sex objects (the second sex) but refer to independence and achievement. Women are now a significant milestone in realizing the success of future generation development. PKH participants are recorded in the Integrated Database. This certainly facilitates the Batu City Government in conducting data collection in order to assist, foster and implement this policy.

The poverty reduction policy was formed as an innovation policy from the Batu City Social Office through Mayor Regulation No. 26 of 2015 concerning the Acceleration of Poverty Management through the Partnership Pattern of the KPM Family Program Hope. According to researchers in this policy, women become the object of poverty reduction policies through the KPM. This is based on the observations of researchers when conducting interviews with one of the speakers who said that in the process of making this policy decision until the KPM involvement is not directly involved.

\section{PKH-KPM Policy Targets}

The targets in the PKH-KPM policy are all women who are PKH participants in Batu City. This is based on Batu Mayor Regulation No 26 of 2015, Chapter V Article 6 concerning KPMs. The implementation of PKH itself in Batu City began in 2013 until now. Women's groups that are PKH participants or PKH participants who are vulnerable to social and economic problems are the main targets of this policy. Women in this policy are the primary support or the main milestone in realizing the success of development for future generations.

Factors why women have an essential role in this policy. The results of this policy cannot be felt directly, but have an uncertain timeframe because discussing the problem of poverty, and all aspects must be supportive. Children with good health and education quality are expected to be the exit for them to escape the poverty chain. Therefore, participants in this policy must be genuinely committed to carrying out their obligations accurately and reliably. This policy targeted PKH women because, in order to receive aid in the form of money, it would be easy to demand their 
commitment in carrying out obligations during the implementation of this policy. Data that is undoubtedly one of the supporting factors in facilitating the implementation of this policy both in supervision, assistance and guidance for KPM, because their data has been recorded in an integrated database.

b. Implementation and Dynamics of Good Governing Poverty Alleviation through PKH - KPM Policy in Poverty Reduction in Batu City.

1. Implementation of PKH - KPM Policy in Poverty Reduction in Batu City.

Good Governing Poverty Alleviation is a poverty alleviation program by implementing the Good Governance governance model in this context in the Harapan Harapan Family Program - KPM, which involves state, society and private sector actors. Following the concept of Good Governance involving 3 actors namely the government, private sector and the community, it is undoubtedly following the Mayor's Regulation No. 26 of 2015 concerning the Acceleration of Poverty Management through the Partnership Pattern of the KPM Family Program Harapan. Therefore, the following explanation regarding the process of the policy:

\section{1) Establishing Implementing Organizations}

In the implementation of the policy to accelerate the handling of the problem of poverty through a KPM in Batu City, the initial step taken is to establish an implementing organization that is responsible for implementing this policy. The Social Service as an organization implementing this policy, which has been mandated by the Mayor of Batu. This is based on the main tasks and functions of the Batu City Social Office, which has a significant role in overcoming social problems, specifically in this study related to poverty.

\section{2) Batu City Social Service Scope Planning}

After the establishment of the implementing organization, of course, internal planning within the Batu City Social Office is needed to harmonize thoughts or perceptions related to this policy. Poverty problems in the field and determine effective ways or methods as instruments for solving poverty problems in the field. In the process, the internal scope, in this case, the Kota Batu Social Service, together with the Kota Batu PKH Team, certainly looked at the facts of the poverty problem in Kota Batu and then conducted a study of the problem to determine an effective method or method for overcoming the poverty problem. In this case, through the countermeasures policy that will be made. After the problem assessment has been completed, a budget is needed to support the realization of the policy; budgeting is done when the number of recipients is certain.

Please Cite This Articel As : Indah Dwi Maulana et al., "Good Governing Poverty Alleviation” Through The PKH Policy 


\section{3) Socialization}

The socialization process is one of the essential processes in implementing this policy. A practical implementation process that is the implementation carried out directly to the existing KPM-KPM so that implementing organizations sees firsthand the condition of KPM businesses that will be partnered with the private sector. However, the indirect socialization process was still carried out so that the general public was aware of this policy. This policy socialization process is carried out directly or indirectly. Direct socialization is carried out so that implementing organizations know the real conditions of KPM in the field. Meanwhile, indirect socialization is carried out so that the general public is aware of this policy.

\section{4) Formation of Partnership}

After the socialization process is completed, the next process is the formation of partnerships. The formation of partnerships with the private sector went through a process where the PKH Team, together with Batu City Social Office held a private sector joint discussion. And when they agree and are enthusiastic, an MoU with the KPM itself will be signed at the Batu City Social Service Office. In this case, even though the SOP has not yet been explicitly made related to the policy, the Batu City Social Service has formed a partnership to raise awareness and private sector concern over the problem of poverty in Batu City.

\section{5) Coaching and Assistance}

In the process of fostering and assisting the private sector, the sector coordinates with each of the facilitators who have been determined to cooperate in the implementation of KPM assistance. Implementation of guidance and assistance in making products from KPM through efforts coordination with the private sector in determining better quality and quantity needed. The assistance process is not only limited to making a processed product, but in the mentoring process is done to add insight and change the mindset of KPM.

In mentoring, each facilitator provides insight to KPM not only about their economic endeavours but also about education, health and management of the family system as well as during the mentoring. This assistance process is used as a means to convey information information that is considered necessary in building insight and can change the mindset of KPM. Each mentoring meeting, the facilitators, make this momentum to see also how the development of the KPM in marketing their products to the private sector, the final result will be made a report by the mentor and used as evaluation material.

At this stage, to establish a partnership relationship with the Batu City Social Service as the person responsible for accelerating the handling of poverty problems through the KPM- 
PKH partnership pattern in its implementation, only making agreements following the contents of the MoU without having its SOP in implementing this policy. Of course, according to the researchers, the policy of accelerating the handling of the problem of poverty through the KPM-PKH partnership pattern has been well integrated, both in the fields of education, health and economics, only that the policy has not been regulated related to standard operating procedures for implementing this policy.

\section{Private Sector Role as partners}

The private sector undertook a partnership pattern that also signed a memorandum of understanding with KPM through the Batu City Social Service, namely: Royal Orchids Garden Hotel \& Condominiums with the Chairperson of the KPM (KPM) Sarirejo, Sumberejo Village, Batu City. The partnership was carried out on September 3, 2015, at the Batu City Social Service Office. The roles and tasks are as follows:

1. Daud Arifin as General Manager acting for and on behalf of the Royal Orchids Garden Hotel \& Condominiums will do:

a) Providing coaching and assistance in developing productive economic efforts or efforts carried out.

b) Assist the Regional Government in efforts to accelerate the handling of the problem of poverty through a partnership

c) Facilitating the development of a productive microeconomic business carried out

2. Ibu Sukarti as the Chair of the Group acting for and on behalf of the KPM (KPM) of the Harapanere Family Program (Sarirejo) in Sumberejo Village will conduct:

a) Fully support this collaboration program through an $\mathrm{MoU}$

b) Provide commitment in implementing partnership patterns to accelerate poverty resolution in Batu City by optimally developing productive economic businesses.

c) Participate in coaching and training in implementing partnership patterns both by the private sector and government agencies.

The above agreement is based on the results of the MoU from the two Parties who are mutually committed in implementing this policy. The role of the private sector is one of the important actors for the productive economic development of KPM, for example, KPM Sarirejo, Sumberejo Village, Batu City. As for the number of KPM that formed a partnership and had signed an MoU, there was 8 KPM, the data are as follows:

1. Royal Orchids Garden Hotel \& Condominiums with the Chairperson of the (KPM) Sarirejo.

2. Social Service and Workforce of Batu City with PPTKLN Wonojati Malang Work Training UPT.

3. PT. Bunga Wangsa Sejati (Jawa Timur Park) (KPM) Sejahtera Mandiri.

Please Cite This Articel As : Indah Dwi Maulana et al., "Good Governing Poverty Alleviation” Through The PKH Policy - Independent Women's Group in Poverty Reduction in Batu City (Study at Batu City Social Service): Journal of Local Government Issues (LOGOS), https://doi.org/10.22219/LOGOS.Vol2.No2.193-209 
4. PT. Mutiara Indah Sejahtera and Agropolitan TV with (KPM) Mawar Indah, Oro-Oro Ombo

Village, a type of business in the intestinal crisis.

5. Museum Angkut with the KPM (KPM) Sari Rasa.

6. The Head of Permata Agro Mandiri and the Director of Bagus Agriseta Mandiri with (KPM) Sumber Rejeki.

7. Director of PT. Bakti Batu Sejahtera with (KPM) Mawar.

8. Purnama Hotel and Palem Sari Hotel with (KPM) Sri Rejeki.

The list of names above is a private list of sectors which have partners and made agreements through an MoU with KPM. The type of business in each KPM varies depending on the ability of the KPM and the needs of the private sector itself. Up to now, there have been 25 KPMs formed, but of the 25 KPMs, only 8 KPMs have partnered with the private sector through the MoU process. $8 \mathrm{KPM}$ is the first $8 \mathrm{KPM}$ in this poverty reduction policy. So that the other KPM partners are still looking for partners through the Batu City Social Service

c. The dynamics of PKH - KPM policy implementation in Poverty Alleviation in Batu City.

1) Human Resources Capacity of the KPM

Human resources from KPM indeed become one of the critical points in the implementation of this policy. If KPM human resources are still lacking or below excellent standards of knowledge of the business they are going to run, it will hamper the implementation as well as the inadequacy of this policy in the field. The human resources of the KPM are still below the standard to meet the private demands of the existing sector. From this statement, in this case, the researcher sees that not all KPM make efforts according to their abilities, but see the private sector needs or demands. This is, of course, legitimate, because the private sector certainly wants a mutually beneficial partnership. Therefore, training becomes a mandatory requirement that must be obtained for this KPM.

One example, KPM, which stopped entirely in implementing this policy is KPM Sejahtera Mandiri Desa Temas with a worm livestock business, which is chaired by Mrs Suparmi Ningsih. KPM Sejahtera Mandiri is one of the KPM that already has a business embryo before the poverty reduction policy through this partnership pattern exists - starting in 2014 until 2017. Initially, based on the narrative of Suparmi, for worm cattle, it is only suparmi mothers who are quite aware of their livestock techniques. They all learn from one another. For their development, they developed and benefited, but over time the worm harvesting period which should be farmed suddenly disappears and until now this supari mother and other group members still do not know the cause of the crop failure.

KPM Sejahtera Mandiri partnered with Jatim Park Group. Due to a request from the East Java Park for white rat cattle, KPM Sejahtera Mandiri made white rat cattle as their side business to be able to meet the demand or needs of East Java Park itself. Several groups try to fulfil the demand from the

Please Cite This Articel As : Indah Dwi Maulana et al., "Good Governing Poverty Alleviation” Through The PKH Policy - Independent Women's Group in Poverty Reduction in Batu City (Study at Batu City Social Service): Journal of Local Government Issues (LOGOS), https://doi.org/10.22219/LOGOS.Vol2.No2.193-209 
private sector but from the private sector itself is just waiting for its development without any form of training given to them before. Of course, this makes it difficult for KPM Sejahtera Mandiri in the process of white rat cattle according to demand.

There are other obstacles, namely, land, weather and pest problems. The land used for worms and white rats is one of the group members' land, and the house land is a contract house that has a usage period, with uncertain and permanent land conditions, this is one of the obstacles for this KPM. As well as the weather constraints they faced during the worm livestock process, where it was the rainy season and the wind so that the livestock media was too wet, so they had the initiative to provide plastic cover over the worm media. After the rainy season and the wind at that time when the harvest of worms that had been expected to be many, it turns out that a lot was lost. With this incident, KPM Sejahtera Mandiri together with PKH companions did not give up, and they continued to carry out worm cattle, an obstacle when trying to try cattle again during the dry season, by taking care as usual. At the time of harvest, they even suffered losses again. Another obstacle is pest disorders (caterpillars and ants). To cope with these pests, mothers, together with PKH facilitators, make maintenance schedules such as providing food and others.

For the business of mice, the obstacles faced are the same as those of worms, one of which is weather and late feed. At the time the rats gained profits did not return even losses because many rats died. The incident was caused due to the late feeding of the mice because of its focus on the worm. Until finally KPM Sejahtera Mandiri gave up on the worm and rat cattle business and chose a total vacuum.

The role of the private sector itself from the start of the partnership to their total halt in the worm and white rat cattle business is just an $\mathrm{MoU}$; they want to see its development and visit from time to time. However, before they visited, the business that was done stopped with various obstacles encountered. In the process, the private sector does not provide training at all for their supplies in the worm and rat livestock business.

The role of the Batu City Social Service is to provide assistance and supervision carried out by authorized PKH facilitators at KPM Sejahtera Mandiri. Assistance provided in the form of worm cattle media. However, in the process of submitting proposals for these tools and materials, they did not get what they asked for the proposal. The proposal is to make bamboo shelves for worm cattle, but what is given is crates. And at that time there was no training done for KPM.

In this study, researchers made KPM Sejahtera Mandiri become one of the examples of implementing policies that led to the powerlessness of KPM to continue their efforts as an effort to empower the local government. KPM Sejahtera Mandiri is 1 of 8 KPM that has conducted private

Please Cite This Articel As : Indah Dwi Maulana et al., “Good Governing Poverty Alleviation” Through The PKH Policy - Independent Women's Group in Poverty Reduction in Batu City (Study at Batu City Social Service): Journal of Local Government Issues (LOGOS), https://doi.org/10.22219/LOGOS.Vol2.No2.193-209 
sector, joint partners. However, the facts on the ground show how the obstacles in this policy during the implementation process so that this KPM can be said to be unsuccessful due to various factors.

\section{2) Private enthusiasm for different sectors}

The private sector enthusiasm is undoubtedly an essential point in the implementation of this policy. However, it could be that in the implementation of private sector enthusiastic different sectors. Every private sector sees the feedback they will get. In this policy, the private sector is not required to do a partnership with KPM, and the private sector is given the most comprehensive opportunity to play an active role in poverty alleviation. It is stated in Perwal Number 26 of 2015 CHAPTER III concerning the participation of private parties article 4. There is no obligation for them to have a partnership with KPM. Private sectors are only given active rights in overcoming the problem of poverty, but their obligations are not included in overcoming poverty.

Different sectors of private enthusiasm can also be seen when implementing this policy in the field. After the obstacles experienced by KPM Sejahtera Mandiri based on the observations of researchers at the time of assistance, the East Java Park during this effort never gave training or coaching efforts either directly or indirectly to the KPM Sejahtera Mandiri. East Java Park is just waiting for its development. This is based on the results of discussions between researchers and PKH facilitators and KPM Sejahtera Mandiri mothers, 29/04/2019 at the home of Suparmi Ningsih as the Chairperson of KPM Sejahtera Mandiri.

Meanwhile, different things were felt by KPM Sari Rejo, Sumberejo Village. With the type of wet cake business that was partnered with the Royal Orchids Garden Hotel \& Condominiums. Based on the observation of researchers when researching the field that, KPM Sari Rejo is a KPM that is considered successful during the poverty reduction policy process carried out. In the beginning of the KPM Sari Rejo, they were genuinely formed after the Mayor's Regulation Number 26 of 2015 concerning the Acceleration of Poverty Management through the Partnership Pattern of the KPM Family Program Harapan.

Based on the acknowledgement from Mrs Sukarti as the Head of KPM Sari Rejo, PKH facilitators coordinated with Batu Orchid Hotel regarding what they needed. However, the orchid hotel gave KPM Sari Rejo the chance to choose what they could do. Finally, KPM Sari Rejo decided to do a wet cake business which would later be sold to the hotel orchid. In its journey, KPM Sari Rejo also encountered obstacles such as, often the failure of the products produced was not following what was expected. From the failure experienced by the PKH KPM companion, it always provides direction and motivation so that the KPM mothers remain enthusiastic in this effort. The form of support was not only from PKH facilitators, but the hotel orchid also provided a stimulus to keep them motivated in this effort, by coordinating directly with the KPM and PKH companions at the orchid hotel at that

Please Cite This Articel As : Indah Dwi Maulana et al., "Good Governing Poverty Alleviation” Through The PKH Policy 
time. KPM, together with PKH facilitators, coordinated what they needed to improve so that the products produced were successful and in line with what they expected. Until after the mutual assistance, KPM Sari Rejo has so far partnered with the orchid hotel very well. This is proven by the fact that the stock of wet cakes in the hotel orchid, one of which is currently the product of KPM Sari Rejo's mothers.

It can be seen from the two KPM above with various obstacles experienced, that the private sector enthusiasm is very different. Private activity the sector in conducting coaching is very much different if we look at the two KPM above. The need for an active private sector role in this policy has dramatically helped KPM efforts to be able to truly empower them to escape the poverty that is holding them back.

\section{CONCLUSION}

This policy has been well integrated. However, in its implementation or implementation at the regional level, in this case, Kota Batu has not yet demonstrated an integration model because there is something that has not manifested normatively. What is intended is that the Standard Operating Procedures (SOP) has not been regulated in this policy. This policy does not have an SOP in its implementation. Currently, this policy only uses a form of partnership in the form of an MoU that was built with entrepreneurs in Kota Batu.

There is a KPM that is currently active in its activities, namely the relationship between the Royal Orchids Garden Hotel \& Condominiums partner with the Head of the KPM (KPM) Sarirejo, Sumberejo Village, Batu City. Also, there are KPM that stopped doing a business product that has partnered at the beginning of the MoU with the private sector, namely the relationship between partners of PT. Bunga Wangsa Sejati (Jawa Timur Park) with the KPM (KPM) Sejahtera Mandiri, Temas Village, a type of worm livestock business.

The dynamics that occur in this policy are caused by several factors that occur, such as 1 . The capacity of human resources in this KPM is still lacking or still below the standard so that not all KPM can quickly meet the private demands of the existing sector, and one example is the relationship between partners of PT. Bunga Wangsa Sejati (Jawa Timur Park) with the KPM (KPM) Sejahtera Mandiri in the Village of Temas, the type of worm livestock business is not going well due to lack of knowledge from KPM in managing the worm livestock business that is produced to meet the demand from the private sector, so that the business Worm cattle produced by KPM Sejahtera Mandiri, Temas Village, with various obstacles, stopped completely. So that it can be said that this policy does not work optimally in its implementation 2. Private sector enthusiasm is different, the enthusiasm of the private sector is essential because it will affect the network of partnerships that will be run with KPM later, it cannot be denied that every private sector would want profit feedback they will get. The difference can be seen from the private sector's activity in conducting coaching so

Please Cite This Articel As : Indah Dwi Maulana et al., "Good Governing Poverty Alleviation” Through The PKH Policy 
that there are significant differences in the two KPMs due to the enthusiasm and private activity of the sector in conducting assistance.

\section{REFERENCES}

Barr, N. (2012). Economics of the welfare state, Oxford university press.

Badan Pusat Statistik “ Garis Kemiskinan” https://www.bps.go.id/subject/23/kemiskinan-dan$\underline{\text { ketimpangan.html }}$

Badan Pusat Statistik, "Persentase Penduduk Miskin" https://www.bps.go.id/pressrelease/2018/07/16/1483/persentase-penduduk-miskin-maret-2018-turunmenjadi-9-82-persen.html.

Bogdan, R. C. and S. K. Biklen (2007). "Research for education: An introduction to theories and methods." Boston, MA: Allen and Bacon.

Meijers, E. and D. Stead (2004). Policy integration: what does it mean, and how can it be achieved? A multidisciplinary review. Berlin Conference on the Human Dimensions of Global Environmental Change: Greening of Policies-Interlinkages and Policy Integration. Berlin.

Miles, M. B., et al. (1994). Qualitative data analysis: An expanded sourcebook, sage.

Miftah Thoha (S.H Sarundajang, 2005), dalam jurnal Penerapan Good Governance Dalam Tata Kelola Pemerintahan Di Kantor Kecamatan Modoinding Kabupaten Minahasa Selatan, Natalia Gratia Sanding, Marlien Lapian, Josef Kairupan, Jurnal Jurusan Ilmu Pemerintahan, Volome 1 No. 1 Tahun 2018, Fakultas Ilmu Sosial dan Politik Universitas Sam Ratulangi, ISSN : 2337 - 5736.

Poerwanti, E. (1998). "Dimensi-dimensi riset ilmiah." UMM Pers, Malang.

Soeun, S. (2005). Kebijakan pengentasan kemiskinan dalam perspektif Good Governance:: Studi kasus Program Pemberdayaan Daerah dalam mengatasi dampak krisis ekonomi (PDM-DKE) di Desa Ambarketawang Kecamatan Gamping Kabupaten Sleman, Universitas Gadjah Mada.

Sugiyono (2008). "Metode penelitian bisnis." Bandung: Pusat Bahasa Depdiknas.

Sugiyono (2014). "Metode Penelitian Kuantitatif, Kualitatif dan R\&D." Alfabeta. Bandung.

Suharto, E. (2005). Membangun Masyarakat Memberdayakan Rakyat Kajian Strategis Pembangunan $\underline{\text { Kesejahteraan Sosial dan Pekerjaan Sosial, PT Refika Aditama. }}$

Sukmana, O. (2017). "Konsep dan Desain Negara Kesejahteraan (Welfare State)." JURNAL SOSIAL POLITIK 2(1): 103-122.

Susetio, W. (2007). "Konsep Welfare State dalam Amandemen UUD 1945: Implementasinya dalam Peraturan Perundang-Undangan (Beberapa Tinjauan dari Putusan MKRI)." Lex Jurnalica 4(2).

Dokumen Rencana Kerja Pemerintah Daerah (RKPD Kota Batu, 2017)

Please Cite This Articel As : Indah Dwi Maulana et al., "Good Governing Poverty Alleviation” Through The PKH Policy - Independent Women's Group in Poverty Reduction in Batu City (Study at Batu City Social Service): Journal of Local Government Issues (LOGOS), https://doi.org/10.22219/LOGOS.Vol2.No2.193-209 
Peraturan Menteri Sosial Republik Indonesia Nomor 1 Tahun 2018 tentang Program Keluarga Harapan.

Peraturan Menteri Sosial Republik Indonesia Nomor 18 Tahun 2017 tentang Pelimpahan Kewenangan Dekonsentrasi Dan Penugasan Tugas Pembantuan Kepada Dinas Sosial Daerah Provinsi dan Dinas Sosial Daerah Kabupaten/Kota Tahun Anggaran 2018.

Peraturan Wali Kota Nomor 26 Tahun 2015 tentang Percepatan Penanganan Masalah Kemiskinan melalui Pola Kemitraan Kelompok Perempuan Mandiri Program Keluarga Harapan

Peraturan Menteri Sosial Republik Indonesia Nomor 18 Tahun 2017 tentang Pelimpahan Kewenangan Dekonsentrasi Dan Penugasan Tugas Pembantuan Kepada Dinas Sosial Daerah Provinsi Dan Dinas Sosial Daerah Kabupaten/Kota Tahun Anggaran 2018.

Peraturan Wali Kota Nomor 26 Tahun 2015 tentang Percepatan Penanganan Masalah Kemiskinan melalui Pola Kemitraan Kelompok Perempuan Mandiri Program Keluarga Harapan. 